[Vol. 101

\title{
NOTES
}

\section{MANDATORY DISMISSAL OF PUBLIC PERSONNEL AND THE PRIVILEGE AGAINST SELF-INCRIMINATION}

The extraordinary amount of legislative investigation into subversion and corruption in government in recent years has resulted in the frequent exercise of the privilege against self-incrimination by witnesses, many of whom have been officials or employees of local and state governments. The wide publicity given to the investigations has aroused much interest in legislation-existing and proposed-which requires the automatic dismissal of government personnel who refuse to reply to the investigators' questions on the grounds of self-incrimination. The purpose of this Note is to examine the practical and constitutional aspects of this legislation in light of the constitutional privilege which it affects.

The Privilege.-The Federal Constitution ${ }^{1}$ and the constitutions of forty-six states ${ }^{2}$ afford to individuals the privilege of refusing to testify to matters which may tend to incriminate them. Individuals may not be compelled to so testify. The privilege extends to testimony given before various forms of legislative investigatory bodies as well as to testimony given in the courts ${ }^{3}$ and it has usually received a broad construction in favor of the right which it was intended to secure. ${ }^{4}$ The purpose of the right against self-incrimination is to prevent use of the inquisitorial methods of investigation which prevailed before the right was recognized, ${ }^{5}$ and to foster complete independent examination of the facts by the investigating authority. ${ }^{6}$ Manifestly, exercise of the privilege closes off one source of

1. U.S. Const. AMEND. V.

2. In the remaining states, Iowa and New Jersey, the privilege is a part of the common law. See State v. Height, 117 Iowa 650, 91 N.W. 935 (1902); State v. Miller, 71 N.J.L. 527, 60 Atl. 202 (1905) ; State v. Zdanowicz, 69 N.J.L. 619, 55 Atl. 743 (1903). Constitutional clauses are collected in 8 WIGMORE, EvIDENCE $\$ 2252$ n.3 (3d ed. 1940).

3. See Commonwealth v. Prince, 313 Mass. 223, 46 N.E.2d 755 (1943), aff'd, 321 U.S. 158 (1944) ; Emery's Case, 107 Mass. 172 (1871); State v. King, 342 Mo. 107, 119 S.W.2d 322 (1938); Matter of Doyle, 257 N.Y. 244, 177 N.E. 489 (1931); In re Hearings, 187 S.C. 1, 196 S.E. 164 (1938). See EMERSON AND HABER, Political and Civil Rights in the United States $452-456$ (1952).

4. See, e.g., Counselman v. Hitchcock, 142 U.S. 547, 548 (1892) ; Blum v. State, 94 Md. 375, 51 Atl. 26 (1902); Moll v. Danziger, 238 Mich. 39, 213 N.W. 448 (1927) ; Matter of Doyle, 257 N.Y. 244, 177 N.E. 489 (1931); People v. Cassidy, 213 N.Y. 388, 107 N.E. 713 (1915) ; Commonwealth v. Frank, 159 Pa. Super. 271, 48 A.2d 10 (1946); State v. Vroman, 45 S.D. 465, 188 N.W. 746 (1922) ; Powell v. Commonwealth, 167 Va. 558, 189 S.E. 433 (1937); Thornton v. State, 117 Wis. 338, 93 N.W. 1107 (1903).

5. See 8 Wrgmore, EVIDENCE $\$ 2250$ et seq. (3d ed. 1940); Inbau, SeLFINCRIMINATION 6-8 (1950).

6. Ibid. See also text at note 75 infra. 
information and for this reason it has undergone some authoritative criticism. ${ }^{7}$ Since it is the purpose of this Note to examine the privilege against self-incrimination as it is affected by a particular area of legislation, the many arguments pro and con the privilege will be discussed only insofar as they bear on the constitutionality and/or desirability of that legislation.

The Statutes.-The enactments already in existence ${ }^{8}$ and those proposed follow substantially the same form. ${ }^{9}$ They provide for the dismissal of public employees who refuse to testify on grounds of self-incrimination or who refuse to waive immunity from prosecution, ${ }^{10}$ and they proscribe from further public service those who are dismissed pursuant to the terms of the statute.

The avowed purpose of the statutes is to remove from public office those who would obstruct investigation into the affairs of government by claiming their right against self-incrimination. ${ }^{11}$ The statutes make no distinctions as to the type of office holder, the nature of the questions asked, or the duties performed by the person under question. The very fact

7. E.g., 5 Benthaim, Rationale of Judicial Evidence 207 et seq. (1827); Appleton, EVIDENCE 129-134 (1860) ; 8 WigMore, EVIDENCE, §2251; McCormick, Tonorrow's Law of Evidence, 24 A.B.A.J. 507, 511 (1938).

8. LA. Rev. Stat. tit. 33, §2426 (1950) ; New York City Charter, \$903 (1943); Philadelphia Home Rule Charter, $\$ 10-110$ (1951). Similar statutes were proposed in Illinois in 1948 and 1949. See Note, 44 ILL. L. REv. 112 (1949). For a statute proposed in the Pennsylvania General Assembly see note 9 infra. Governor Driscoll of New Jersey has called for a similar measure in that state. N.Y. Times, Jan. 14, 1953, p. 22, col. 4. The New York State Legislature approved a measure making dismissal from party office automatic for political leaders who refuse to waive immunity betore investigative bodies. N.Y. Times, March 23, 1953, p. 18, col. 3 .

9. E.g., the Pennsylvania proposal provides: "Whoever being an employe of the Commonwealth of Pennsylvania or any of its agencies or political subdivisions after lawful notice of process wilfully refuses or fails to appear before any court or judge any legislative committee or any officer, board or body authorized to conduct any hearing or inquiry or having appeared refuses to testify or to answer any question relating to the affairs of the government of the Commonwealth or any of its agencies or political subdivisions or to the conduct of any officer or employe of the Commonwealth or any of its agencies or political subdivisions on the ground that his testimony or answers would tend to incriminate him or shall refuse to waive immunity from prosecution of any matter about which he may be asked to testify before the court or at any hearing or inquiry shall immediately forfeit his term or tenure of office position or employment his office position or employment shall be vacant and he shall not be eligible thereafter to election or appointment to any position in the service of the Commonwealth or any of its agencies or political subdivisions." Senate Bill 94, General Assembly of Pennsylvania (Feb. 9, 1953). The bill was introduced by Senator Albert $R$. Pechan who also introduced the controversial Pennsylvania Loyalty Act. PA. STAt. ANN. tit. 65, \$\$212-225 (Purdon Supp. 1951). See Byse, $A$ Report on the Pennsylvania Loyalty Act, 101 U. of PA. L. REv. 480 (1953).

10. Legislation granting immunity from prosecution has been a favorite method of dispensing with the privilege. See 8 WIGMORE, EVIDENCE, $\$ 2281$ n.11 for a collection of statutes. Where the witness is immune from prosecution he cannot incriminate himself and the privilege necessarily ceases. For problems arising as to the extent of such immunity see the famous case of Counselman v. Hitchcock, 142 U.S. 547 (1892).

11. With dismissal as the main purpose it is difficult to understand why the statutes require a waiver of immunity. If immunity was granted, the witness would have to testify and if, in so doing, he disclosed that which the investigation sought, he could be dismissed. This would obviate the necessity for the present statutes. Obviously the framers of the statutes seek prosecutions as well as dismissal. 
that they are so all-inclusive creates several areas of doubt as to their constitutionality as well as to their general desirability.

\section{Problems Under State Constitutions}

As Applied to Offices Created by a Constitution.-Apparently no cases have yet arisen in which the statutes have been applied to persons who hold their government positions by virtue of the constitution of their state. It would seem, however, that the statutes are intended to apply to anyone in public employ including constitutional officers. ${ }^{12}$ The proposed Pennsylvania statute, ${ }^{13}$ for example, begins with the words, "Whoever being an employe"; it might be argued that this would exclude constitutional officers ${ }^{14}$ were it not for the fact that a later clause says he shall forfeit his term (or) tenure of office (or) position (or) employment. This suggests that all government personnel are within the purview of the statute.

As to many offices created by constitutions, and to which the statutes presumably apply, the constitutions not only describe the office but set forth the qualifications for selection to those offices, the methods by which such officers may be removed, and the grounds for removal. A prescription by a constitution of the means and causes for removal is exclusive 15 and it has often been held that the legislature may not alter or add to these provisions in any manner. ${ }^{16}$ Certainly the legislature by providing for dismissal in the present statutes has added a cause not set forth in the constitution; that is, an officer may, in addition to the reasons set forth in the instrument creating the office, be removed for refusing to incriminate himself.

In addition to adding a cause for removal, the statutes alter constitutional requirements as to the qualifications for taking office. Where it is provided in a statute that a dismissed employee shall be ineligible for election or appointment to state office, ${ }^{17}$ a candidate for such office must not only meet the qualifications set forth in the constitution but he also must never have been dismissed pursuant to this statute.

The problem of alteration of constitutional requirements arises where the constitution of a state establishes the qualifications of an elector. Thus, a Pennsylvania case held that an individual could not be disqualified from voting for the reason, additional to provisions in the constitution, that he

12. See Note, 64 U.S.L. Rev. 561 (1930).

13. See note 9 supra.

14. For distinctions among various types of officers and employees and the methods available for their dismissal see Note, 99 U. of PA. L. REv. 829 (1951); and see Hetkowski v. Dickson City School District, $141 \mathrm{~Pa}$. Super. 526, 15 A.2d 470 (1940).

15. 1 Cooley, Constitutional Limitations 139 (8th ed. 1927) (cases cited).

16. E.g., Lowe v. Commonwealth, 3 Metc. 237 (Ky. 1860) ; Commonwealth v. Williams, $79 \mathrm{Ky} .42$ (1880); State v. Brunk, 326 Mo. 1181, 34 S.W.2d 94 (1930); People v. Howland, 155 N.Y. 270, 49 N.E. 775 (1898); Commonwealth v. Gamble, $62 \mathrm{~Pa} .343$ (1869); Commonwealth v. McCombs, 56 Pa. 436 (1867). But cf. State ex rel. LaFollette v. Kohler, 200 Wis. 518, 228 N.W. 895 (1930).

17. See note 9 supra. 
refused to answer incriminating questions. ${ }^{18}$ Nor could Civil War deserters be disenfranchised in Pennsylvania since the right to vote is conferred by the constitution and is therefore beyond reach of the legislature. ${ }^{19}$ The same "exclusive doctrine" applies to legislative change in the qualification for office. ${ }^{20}$ It has been held that the legislature cannot require residence over and above the time specified in the constitution as a prerequisite to election, ${ }^{21}$ and that the legislature cannot require candidates for constitutional office to have legal experience. ${ }^{22}$ These cases support the conclusion that legislatures cannot add as a qualification for office the requirement that a person shall not have been removed from public office for exercising a specific constitutional right. Accordingly, insofar as the present statutes add to the constitutional requirements for taking, or being removed from, public office they are probably invalid under state constitutions.

Dismissal as Compulsion.-There is also a serious question as to whether or not the instant statutes violate the self-incrimination provisions in the various constitutions, which all forbid the states to use "compulsion" or to "compel" any one to give testimony which may be self-incriminating. ${ }^{23}$ The argument here in behalf of the statutes is that they do not compel a person to testify or to waive his right; the person questioned may still claim his testimonial privilege, but if he chooses to do so he may not remain in government employ.

This argument assumes that the choice is a real one. Particularly in cases where the employee's dismissal results from a failure to testify in investigations regarding subversive activities, the employee is faced with the "choice" of waiving his constitutional privilege or losing his job under circumstances unquestionably resulting in a stigma of "disloyalty"; it is not unreasonable to term this a punishment, ${ }^{24}$ particularly since the statutes provide not only for dismissal, but for permanent proscription from service. ${ }^{25}$ The legislature cannot assault the constitutional privilege by the indirect, though effective, process of requiring the surrender of a person's

18. Respublica v. Gibbs, 3 Yeates 428 ( $\mathrm{Pa} .1802$ ).

19. McCafferty v. Guyer, $59 \mathrm{~Pa} .109$ (1868).

20. Humphreys v. Walls, 169 Md. 292, 303, 181 At1. 735, 739-40 (1935); Thomas v. Owens, 4 Md. 189, 223 (1853); Page v. Hardin, 8 Mon. 648, 661 (Ky. 1848); See Cooley, op. cit. supra note 15; Mechen, Public OfFicers, ch. 3, \$96 (1890).

21. People v. McCormick, 261 Ill. 413, 103 N.E. 1053 (1913) ; Evansville v. State, 118 Ind. 426, 21 N.E. 267 (1888). But cf. State v. McAllister, 38 W. Va. 485, 18 S.E. 770 (1893).

22. State ex rel. Spruill v. Bateman, 162 N.C. 588, 77 S.E. 768 (1913).

23. 8 Wigmore, Evidence, $\$ 2252$ n.3 (constitutional provisions collected).

24. Cummings v. Missouri, 4 Wall. 277, 323 (U.S. 1866). See dissenting opinion of Edgerton, J., in Bailey v. Richardson, 182 F.2d 46, 67-71 (D.C. Cir. 1950), aff'd withont opintion, 341 U.S. 918 (1951). The affirmance by the Supreme Court was by virtue of a $4-4$ split. Justice Clark who, significantly, wrote the opinion of the Court in Wieman v. Updegraff did not participate. See text at note 52 infra.

25. The Court in United States v. Lovett, 328 U.S. 303 (1946), said that a permanent proscription from any opportunity to serve the government is punishment, "and of a most severe type." Id. at 316. 
means of livelihood if that privilege is asserted. ${ }^{26}$ Though the choice is in form voluntary, in fact it lacks none of the elements of compulsion. ${ }^{27}$

\begin{abstract}
"It would be a palpable incongruity to strike down an act . . . which, by words of express divestment seeks to strip the citizen of rights guaranteed . . . but to uphold an act by which the same result is accomplished under the guise of a surrender of a right in exchange for a valuable privilege which the state threatens otherwise to withhold." 28
\end{abstract}

\title{
Considerations Under The Federal Constitution
}

In light of the recent flood of civil rights cases ${ }^{29}$ before the Supreme Court, there is no doubt that these statutes will have to meet the test of constitutionality under the Federal Constitution. As is the case with most legislation which affects individual liberties, the most important federal constitutional consideration is whether or not the statutes are repugnant to the due process clause of the Fourteenth Amendment.

There is also, however, a possibility that the statutes might violate that clause in the Constitution which declares that no state shall pass a bill of attainder. ${ }^{30}$ The bill of attainder clause was for many years rarely argued before the Supreme Court, but in several recent cases ${ }^{31}$ it has apparently been "rediscovered" and for that reason deserves some notice before discussing the more important subject of due process.

The provision in the instant statutes which is likely to raise the bill of attainder issue is the one which prohibits employees who are dismissed pursuant to the statute from thereafter re-entering public office. ${ }^{32}$ In Cummings v. Missouri, ${ }^{33}$ in invalidating a Missouri constitutional provision which prevented clergymen from preaching unless they took an oath that they had not committed certain acts, the Supreme Court said that a bill of attainder is a legislative act which inflicts punishment without a judicial trial. ${ }^{3 \pm}$ The Court further held that the disability to hold office or employ-

26. Frost and Frost Trucking Co. v. Railroad Commission, 271 U.S. 583, 593 (1925); Alston v. School Board, 112 F.2d 992, 997 (4th Cir. 1940). See also Peck v. Cargill, 167 N.Y. 391, 60 N.E. 775 (1901).

27. See Frost and Frost Trucking Co. v. Railroad Commission, supra note 26.

28. Ibid.

29. See Emerson and Haber, Politrcal and Civil Rights in the United States (1952).

30. U.S. Const. Art. I, § 10.

31. E.g., Garner v. Board of Public Works, 341 U.S. 716 (1951) ; United States v. Lovett, 328 U.S. 303 (1946) ; Bailey v. Richardson, 182 F.2d 46 (D.C. Cir. 1950), aff'd', 341 U.S. 918 (1951).

32. See note 9 sipra.

33. 4 Wall. 277 (U.S. 1866).

34. Id. at 323. Justice Story described a bill of attainder thus: ". . . In such cases, the legislature assumes judicial magistracy, pronouncing on the guilt of the party without any of the common forms and guards of trial, and satisfying itself with proofs, when such proofs are within its reach, whether they conform to the rules of evidence or not. In short, in all such cases, the legislature exercises the highest power of sovereignty, and what may be properly deemed an irresponsible 
ment is a punishment. ${ }^{35}$ More recently the Court held, in United States v. Lovett, ${ }^{36}$ that a permanent proscription from any opportunity to serve the government is punishment, and for this reason a statute so proscribing was a bill of attainder. ${ }^{37}$

Although the instant statutes contain proscriptions from future employment, there are certain features which, it might be argued, distinguish the statutes from bills of attainder. In the first place, bills of attainder have traditionally been aimed at specified individuals, ${ }^{38}$ as in the Lovett case, $^{39}$ or at a well-defined class of individuals, as in the Cummings case. Exactly what would constitute such a class is not clear from the cases; it is difficult to say whether or not all the employees of a state would constitute a class sufficiently well-defined for a bill of attainder. Furthermore, in the bill of attainder cases there has always been an element of punishment for something that had been done in the past. This may not be true under the instant statutes where the public employees are forewarned, i.e., they are not punished for acts prior to the passage of the statute, but rather are they forewarned that they face dismissal and proscription from government service if they refuse to testify after the passage of the act.

Another argument which may be used to deny the attainder features of the instant statutes is the doctrine that a government may proscribe individuals from certain types of employment, when such proscription is based upon the imposition of "reasonable qualifications" for such employment. ${ }^{40}$ Since the establishment of the "reasonable qualification" doctrine, the states have passed many statutes establishing vocational disqualifications. ${ }^{41}$ The validity of these statutes is based upon the "notorious connections between the disqualification and the activity barred." 42 On the basis of this doctrine, a divided Court in Garner v. Board of Public Works of Los Angeles, ${ }^{43}$

despotic discretion, being governed solely by what it deems political necessity or expediency, and too often under the influence of unreasonable fears or unfounded suspicions." 2 StORY, Commentaries on THE ConstrTution $\$ 344$ (5th ed. 1891).

Justice Story points out that originally there were two types of these bills: (1) attainder by which the legislative act inflicted capital punishment, and (2) bills of pains and penalties by which milder degrees of punishment were inflicted. The bill of attainder clauses in the Constitution include both. Ibid. For history of bills of attainder see Davis, United States $v$. Lovett and the Attainder Bogy in Modern Legislation, 1950 WASH. U.L.Q. 13 (authorities cited).

35. 4 Wall. at 321 .

36. 328 U.S. 303 (1945). See Davis, supra note 34; Note, 26 Ore. L. Rev. 78 (1947).

37. This proposition was upheld in Bailey v. Richardson, 182 F.2d 46, 54 (D.C. Cir. 1950), aff'd, 341 U.S. 918 (1951).

38. See Davis, supra note 34.

39. The Act in question actually named the three individuals involved. 57 Stat. 431,450 (1943).

40. E.g., Hawker v. New York, 170 U.S. 189 (1898) (statute forbidding the practice of medicine by any person who had been convicted of a felony); Dent $v$. West Virginia, 129 U.S. 114 (1889) (statute elevating standards of qualification to practice medicine).

41. See Wormuth, Legislative Disqualifications as Bills of Attainder, 4 VAND.

L. REv. 603, 612 (1951).

42. Id. at 612 .

43. 341 U.S. 716 (1951). 
held that a Los Angeles loyalty oath ordinance was not a bill of attainder although persons who refused to take the oath were not eligible for public office or employment in the service of the city. ${ }^{44}$ The Court found that the statute declared "general and prospectively operative standards of qualification and eligibility for public employment." 45 Unquestionably this language could be relied upon in answer to an attainder argument directed against the present statutes, although it would be well to consider the Cummings $v$. Missouri doctrine that the states cannot in effect inflict a punishment under the guise of creating a qualification or attaching a condition to employment. ${ }^{46}$

In discussing the bill of attainder clauses it must be remembered that these clauses were part of the Constitution as originally adopted and therefore preceded by many years the adoption of due process in the Fourteenth Amendment. It is entirely possible that legislation which the Court might once have invalidated as a bill of attainder, would now be declared unconstitutional as a violation of due process. ${ }^{47}$

The "Privilege" to Dismiss Employees and Due Process.-The principal argument for a dismissal statute of the instant variety is that the government is an employer, and as such may hire and fire its employees under such terms and conditions as it may deem necessary; in other words, it is a privilege to be employed by the government and the government may in any way remove or qualify that "privilege" without violating due process. ${ }^{48}$ Attaching the label "privilege" of course is of little help; limitations have been placed upon a government's dealings with other so-called "privileges." For instance, Peck v. Cargill,49 invalidated a statute which called for the revocation of the liquor licenses ("privileges") of persons who claimed

44. The ordinance was passed pursuant to an amendment to the Los Angeles City Charter enacted by the California Legislature. The charter amendment excluded from city employment those who advise, advocate, or teach the overthrow of the government by force. Cal. Stat. 1941, c. 67.

Note, however, that the laws in the Garner case did not contain clauses which banished persons from public service forever. Presumably a disqualified person could always become eligible for public office by signing the loyalty oath. However, the wording of the instant statutes that "he shall not be eligible thereafter to election or appointment to any position. . " would seem to bar any possibility that a dismissed employee might return to public service.

45. 341 U.S. 716, 723 (1950). What the Court did not make clear was that proscription from employment in the Garner case was for failure to take the loyalty oath under the city ordinance, not because of proof that the applicant advocated overthrow of the government. Thus the Court held in effect that because the state enactment set forth reasonable qualifications, the city ordinance was not a bill of attainder. 1866).

46. 4 Wall. 277, 319 (U.S. 1866) ; Ex parte Garland, 4 Wall. 333, 380 (U.S.

47. Apparently this is the attitude of Mr. Justice Frankfurter. See United States v. Lovett, 328 U.S. 303, 326 (1946).

48. In McAuliffe v. New Bedford, 155 Mass. 216, 29 N.E. 517 (1892), which involved the dismissal of a policeman for engaging in political activities contrary to police regulations, the court, per Holmes, J. said, "The petitioner may have a constitutional right to talk politics, but he has no constitutional right to be a policeman." Id. at 220,29 N.E. at 517.

49. 167 N.Y. 391,60 N.E. 775 (1901). 
their right against self-incrimination when called to testify before the liquor commission. The court said that no law can be valid which directly or indirectly compels a party to incriminate himself.50 And although the formation of a corporation is a "privilege" granted by the state it has been held that a statute which called for the revocation of a corporate charter when the officers of that corporation refused to waive their self-incrimination right was invalid. ${ }^{51}$

A recent United States Supreme Court case, Wieman v. Updegraff,52 has indicated that the due process clause of the Federal Constitution limits the right of a state government to deal with its employees. The Wieman case involved an Oklahoma loyalty oath statute ${ }^{53}$ which forbade the public employment of persons who belonged to certain organizations regardless of their knowledge of the character of those organizations. The Court held that the statute violated due process because of the "indiscriminate classification of innocent with knowing activity." 54 As to the "privilege" of working for the government the Court said, ". . . constitutional protection does extend to the public servant whose exclusion pursuant to a statute is patently arbitrary or discriminatory." ${ }^{55}$

The Wieman case may be authority for holding the instant statutes unconstitutional under the Fourteenth Amendment of the Federal Constitution. If, as in the Wieman case, the state may not deal with its employees in a manner which is "arbitrary" or "discriminatory", it may be asked whether it is not "patently arbitrary" to fire an employee for the sole reason that he refuses to waive a right guaranteed him by the constitution. A possible answer to this question was indicated by some members of the Court in the recent case of Orloff $v$. Willoughby.50 In that case the petitioner, a physician, was denied a commission in the Army. One of the reasons why the Army refused to commission petitioner appeared to be that when asked a question pertaining to membership in Communist organizations he replied, "Federal constitutional privilege is claimed." ${ }^{57}$ Although the Court held that it could not review petitioner's assignment to

50. Id. at 395,60 N.E. at 776.

51. State v. Simmons Hardware Co., 109 Mo. 118, 18 S.W. 1125 (1891). In most jurisdictions a corporate officer may not withhold testimony on the grounds that the corporation may be incriminated. See Wilson v. United States, 221 U.S. 361 (1911) ; Essgee Co. v. United States, 262 U.S. 151 (1923); Oklahoma Press Publishing Co. v. Walling, 327 U.S. 186, 196, 204-5 (1946) (authorities collected). And see Meltzer, Required Records, The McCarran Act, and the Prizilege Against Self-Incrimination, 18 U. oF CHI. L. REv. 687, 701 (1951).

52. 344 U.S. 183 (1952).

53. Okla. Stat. ANn. tit. 51, \$\$37.1-37.8 (Supp. 1952).

54. 344 U.S. 183, 191 (1952). But cf. Adler v. Board of Education, 342 U.S. 485 (1952). (1947).

55. 344 U.S. at 192; see United Public Workers v. Mitchell, 330 U.S. 75, 100

56. 345 U.S. 83 (1953).

57. Id. at 90 . The questions were part of a loyalty certificate which applicants for officers' commissions are required to file. 
duty, Mr. Justice Black (with whom Justices Frankfurter and Douglas concurred) dissented, saying,

"The record indicates to me, however, that Dr. Orloff is being held in the Army . . . to punish him for having claimed a privilege which the Constitution guarantees. . . . If an attempt is to be made to punish draftees for asserting constitutional claims, as I can hardly believe it would, it should be done only by an act of Congress. Should such be attempted I would hope that this Court would promptly declare an act to that effect unconstitutional". ${ }^{58}$

The fact that it may be perfectly within the right of a government to fire subversive or corrupt employees does not meet the issue. The statutes considered do not require a showing that the employee is in fact subversive or corrupt, but require his dismissal solely because he refuses to testify on the grounds of self-incrimination. Even in the granting of a privilege the state may not impose conditions which require the relinquishment of constitutional rights. ${ }^{59}$

Several difficulties arise in an attempt to apply the Wieman case to the present statutes. In the first place it is almost impossible to predict how far any due process holding will be extended. The pattern of what does or does not constitute a violation of due process is determined by the facts in each case. ${ }^{60}$ Certainly the fact that a statute violates due process because it excludes unknowing members of subversive organizations does not compel the conclusion that a statute requiring dismissal for failure to testify is in violation of due process.

On its face another difficulty in extending the Wieman holding to these statutes is the ruling that the states would not violate the Federal Constitution even if they eliminated the self-incrimination right altogether. ${ }^{61}$ If a state could constitutionally abandon the privilege, to deny the privilege as an incident of public employment would seem to be no violation of due process. However, the reluctance of the Supreme Court to impose a selfincrimination requirement on the states ${ }^{62}$ need not present so formidable an obstacle to the invalidation of the instant statutes on due process grounds as may at first appear. The precise issue here is not whether a state may fail to guarantee the privilege against self-incrimination, but whether the discharge of employees and their subsequent disqualification from holding office violates due process when such discharge and disqualification is based on the exercise of a privilege which is guaranteed.

58. $I d$. at 97.

59. See Frost and Frost Trucking Co. v. Railroad Commission, 271 U.S. 583, 593-594 (1925).

60. See Brock v. North Carolina, 344 U.S. 424, 427-8 (1953) ; Palko v. Connecticut, 302 U.S. 319 (1937).

61. Adamson v. Calfornia, 332 U.S. 46 (1947); Twining v. New Jersey, 211 U.S. 78 (1908). See Note, 64 Harv. L. Rev. 987, 993 (1951).

62. Ibid. 
A dogmatic statement that the exercise of a constitutional privilege should not be made grounds for dismissal is less than satisfactory particularly where a due process question is involved. Ultimately the conclusion as to whether or not the instant statutes violate due process will depend upon the reasonableness of the action taken as determined by (a) the propriety of drawing an inference of guilt from the silence of the employee called to testify; (b) the effect of the statutes upon certain established principles and practices of this country's system of jurisprudence; and (c) the effect of the claim of privilege upon the competency of employees to render effective service to the government-employer.

(a) Inference of Guilt.-Unquestionably a rationale of the instant statutes is that a person who refuses to answer certain questions has something to hide; it cannot be denied that this is often the case. At least it is reasonable to assume that a person who refuses to answer is more likely to be hiding guilt than one who does not so refuse. There are, however, at least some circumstances under which a person refusing to testify on selfincrimination grounds is not in fact guilty of those actions which are deemed incompatible with continuing in government service.

Probably the most obvious case is that of the so-called "man of principle" who refuses to disclose information to the investigating authority because of an abhorrence of unrestrained inquiry into beliefs. ${ }^{63}$ While some of these witnesses may be using the claim of "principle" as an excuse to cover actual guilt, it is undoubtedly true that many innocent persons are sincere in their objections. Whether or not these people, very often educators, should so claim their privilege on principle is a matter of much controversy among lawyers and the educators themselves. ${ }^{64}$ Nevertheless the fact remains that the privilege is claimed under these circumstances before the various investigating committees.

Another reason why persons plead their privilege although innocent of acts incompatible with government employ arises out of the fact that legislative investigations are roving and generally unhindered by the ordinary rules of evidence which guide the interrogation of witnesses in court. ${ }^{65}$ The refusal to answer questions here is motivated by a fear of being trapped into perjury. Quite often the witness before a committee is interrogated unnecessarily when the committee already has complete evidence as to the matter under question; ${ }^{66}$ the result of such questions is often to lead the

63. See Byse, supra note 9, at 481-484.

64. E.g., The Association of American Universities declared that ". . . invocation of the Fifth Amendment places upon a professor a heavy burden of proof of his fitness to hold a teaching position. . "N.Y. Times, March 31, 1953, p. 13, col. 2. Certain university professors immediately retorted that the Association had "compromised" academic freedom by conceding that invoking the privilege "is an indication of probable guilt." N.Y. Times, April 8, 1953, p. 19, col. 2.

65. See Meltzer, Required Records, The McCarran Act and the Privilege Against Self-Incrimination, 18 U. oF CHI. L. REv. 687, 693 (1951).

66. See id. at 722. "Such compulsion resembles the Soviet tactic of requiring those found guilty, not only to pay for, but also to proclaim their guilt." 
witness into falsehood. ${ }^{67}$ The method of intentionally confusing witnesses by questioning is an age-old one ${ }^{68}$ and often results not only in falsehood by the witness but also in admissions of highly irrelevant matters which, although logically beyond the purpose of the immediate investigation are used in the castigation and attempted conviction of the person questioned. ${ }^{69}$ With such fears in mind, the innocent person is apt to plead his privilege though absent such tactics he might not do so.

Whether or not such uses of the self-incrimination privilege as set forth heretofore are proper is beyond the scope of this Note. ${ }^{70}$ The pertinent fact is that people testifying before investigating committees do exercise the privilege for reasons other than to conceal their guilt of those acts for which the state would wish to dismiss them. It may be argued, however, that because there are many who refuse to answer questions because of guilt, it is reasonable for a state to dismiss by means of the legislation here discussed; the fact that some innocent people will be injured may be outweighed by the great public interest in clean, efficient government. The answer to this argument, discussed below, is that AngloAmerican jurisprudence proceeds on a diametrically opposite assumption: that it is better for an occasional guilty person to escape than to invoke punishment on the innocent.

(b) Other Effects of the Statutes.-The fact that some persons who would be fired might actually be guilty, and the public interest in good government should not be the only factors considered in determining the due process validity of the instant statutes. These considerations should be weighed against other effects that the operation of the statutes will have on this country's system of jurisprudence and procedure.

The most striking effect perhaps is that the presumption of guilt under the statutes is contrary to a fundamental precept of American jurisprudence; i.e., that every person is presumed innocent until proven guilty. ${ }^{71} \mathrm{~A}$ burden of exculpation is placed upon the public officer who faces dismissal. $\mathrm{He}$ either waives his constitutional privilege to be silent or is presumed to be incompetent to serve the government and is automatically dismissed. Aside from what would appear unreasonable in terms of concepts a practical prob-

67. The case of Owen Lattimore, now pending in the courts, might well prove to be an example of such a procedure.

68. See 1 Stephen, History of the Criminal Law of England 325 (1883).

69. See Gellhorn, Report on a Report of the House Committee on Un-Americann Activities, 60 Harv. L. REv. 1193 (1947).

Cleverly worded questions designed to confuse are, of course, a familiar weapon of the trial lawyer. In a court, however, such tactics are under the watchful eye of an impartial judge armed with rules of evidence; not so a legislative investigating committee where the members serve at the same time as examiners and judges. Also it is difficult to justify these tactics in a legislative investigation since theoretically the object is not to prosecute but to establish a basis for legislation.

70. Where the privilege is being used in an unlawful manner, the witness may be cited for contempt. Statutes of the instant variety are thus not made necessary by misuse of the self-incrimination privilege.

71. See State v. Simmons Hardware Co., 109 Mo. 118, 128, 18 S.W. 1125, 1127 (1891); Peck v. Cargill, 167 N.Y. 391, 396, 60 N.E. 775, 777 (1901). 
lem is presented by the great difficulty of proving innocence. For instance, it is a burdensome task for an employee to establish that he is not an advocate of overthrow of the government, or that he has not taken graft or been remiss in his official duties. The burden of exculpation placed upon public servants by the statutes is particularly formidable in legislative investigating committees where the witnesses are not entitled to crossexamination privileges. Especially in light of the proof hardship placed upon witnesses the Supreme Court may well consider the statutes unreasonable on the ground that the constitutional refusal to testify should create "no presumption upon which . . . [a witness is subjected to] . . injurious consequences under the law." 72

Another principle offended by the instant statutes is that traditionally procedure in this country has developed along the lines of independent search for facts by the investigating authority. The privilege against selfincrimination was designed to foster such a procedure. ${ }^{73}$ Dean Wigmore points out that "any system of administration which permits the prosecution to trust habitually to compulsory self-disclosure as a source of proof must itself suffer morally thereby." 74 The more self-disclosure (or the failure to so disclose) is relied upon as evidence of guilt, the greater will be the tendency to be satisfied with incomplete investigation of other sources. $^{75}$ This is, of course, manifest in the instant statutes. The only requirement for dismissal is the claim of the privilege. Therefore, if for some reason the members of an investigating committee wish to remove a person from public employment they need make no accusation or investigation except to call that person before the committee and fire questions at him in the hope that he will claim his privilege.

(c) Claim of the Privilege and Job-Competency.-An argument can be made for the reasonableness of the statutes on grounds other than an inference of guilt; that is, it is incongruous to permit one holding public office to obstruct inquiry into public affairs. ${ }^{76}$ The person who does so obstruct inquiry by claiming his privilege is therefore incompetent to hold public office. There is little doubt that the state can dismiss certain types of employees for exercising constitutional privileges where the exercise of such a privilege is incompatible with the duties of the office in question, ${ }^{77}$ and it is conceivable that the exercise of the self-incrimination privilege would in some instances be incompatible with certain offices. For example, when a policeman called to testify as to his investigation of a crime refuses

72. Commonwealth v. Smith, 163 Mass. 411, 430, 40 N.E. 189, 196 (1895).

73. 8 WIGMORE, EvTDENCE, § 2250.

"The privilege reflected our preference for an accusatorial-adversary system as opposed to the inquisitorial system of the continental countries. .." Meltzer, supra note 65 , at 688 .

74. 8 WIGASORE, EVIDENCE, §2251.

75. Ibid.

76. See Philadelphia Home Rule Charter, $\$ 10-110$ (1951) (annotation).

77. E.g., Christal v. Police Commission, 33 Cal. App.2d 564, 92 P.2d 416 (1939); McAuliffe v. New Bedford, 155 Mass. 216, 29 N.E. 517 (1892); McCrory v. Philadelphia, 345 Pa. 154, 27 A.2d 55 (1942). 
to answer questions relevant to the commission of that crime he is failing to discharge one of the principal responsibilities of his position-to investigate and disclose crime. Under these circumstances, dismissal for failure to testify has been upheld by the courts. ${ }^{78}$

But dismissal cases which have arisen in the states indicate that failure to testify does not in many instances render a person incompetent to perform his duties. When the cause for dismissal had no reasonable relation to the performance of the employee's job, such dismissal has been held invalid ${ }^{79}$ on the grounds that removal from office is a drastic measure and should be exercised only for reasons based upon willful failure to perform official duties. ${ }^{80}$ It has been held, for example, that an attorney's failure to waive immunity from prosecution and testify to incriminating matters before a board of inquiry into unlawful and unethical practices, did not constitute conduct prejudicial to the administration of justice sufficient to warrant discipline. ${ }^{81}$ And failure to waive the privilege did not constitute grounds for denying reinstatement to the bar. ${ }^{82}$ The failure of a judge to sign a waiver of immunity before a grand jury investigation of a murder did not constitute such a violation of his duty as a lawyer to warrant disbarment.83 These cases did not arise under statutes such as the ones with which this Note is concerned. But they do illustrate that dismissal because of the claim of privilege has been considered reasonable by courts only where a job cannot be adequately performed without full disclosure by the person performing the job. ${ }^{84}$ Therefore a general statement that failure to testify

78. Christal v. Police Commission, supra note 77; Drury v. Hurley, 339 Ill. App. 33, 88 N.E.2d 728 (1949).

79. See e.g., State ex rel. Christian v. Barry, 123 Ohio St. 458, 175 N.E. 855 (1931) (unconstitutional to fire a policeman for violation of a department regulation denying the policemen the right to institute civil suits). See Comment, 28 CAL. L. REv. 94 (1939).

80. Cf. Bateman v. State, 214 Ind. 138, 149, 14 N.E.2d 1007, 1011 (1937).

81. Matter of Ellis, 282 N.Y. 435, 26 N.E.2d 967 (1940); Matter of Grae, 282 N.Y. 428, 26 N.E.2d 963 (1940). "The Constitutional privilege is a fundamental right and a measure of duty; its exercise cannot be a breach of duty. . . " Matter of Ellis, 258 App. Div. 558, 572, 117 N.Y.S.2d 800, 813 (1940).

82. Ex parte Marshall, 165 Miss. 523, 147 So. 791 (1933).

83. In re Holland, 377 I11. 346, 36 N.E.2d 543 (1941). "To say that one has an absolute right to a privilege, but if he exercise it he will be punished, is to limit his enjoyment of that right, and unless the circumstances surrounding him or duties placed upon him are of such character as to require . . that he waive the right, we are unable to see wherein it can be said that an individual . . . is either legally or morally guilty of a wrong should he claim the right." $I d$. at $356-357,36$ N.E.2d at 548.

84. The point was raised in one of the few cases arising under the New York City Charter, $\$ 903$ (1943). The case involved the dismissal of an engineer employed in the Bureau of Construction of the New York City Board of Education for claiming his privilege before the House Un-American Activities Committee. In affirming his dismissal, the court said that the defendant's official conduct was affected because "a public employee's official conduct must at all times conform to the obligation of loyalty to the Government." Koral v. Board of Education, 197 Misc. 221, 226, 94 N.Y.S.2d 378, 383 (Sup. Ct. 1950). What the court did not deal with, however, was the fact that the employee was not proved disloyal, but was fired because of his claim of the privilege against self-incrimination. See also Goldway v. Board of Higher Education, 178 Misc. 1023, 37 N.Y.S.2d 34 (Sup. Ct. 1942). 
renders one incapable of exercising the functions of his office is inaccurate; it depends upon the nature of each individual office.

From the standpoint of competency it would seem reasonable to draft the statutes in such a way as to call for the dismissal of persons only when the very nature of the job demands full disclosure: for instance, the policeman who refuses to disclose the facts of a crime which he was employed to investigate. Thus limited, however, it is probable that the statutes would have little appeal to many of their strongest advocates who apparently seek to use them as an "easy-firing" device for "suspected" persons.

From an analysis of the foregoing factors it seems clear that courts in determining the validity of the instant statutes under the due process clause of the 14th Amendment should go beyond the dogma usually offered on each side; i.e., that government employment is a "privilege" which may be taken away or given under such conditions as the government may see fit, or, on the other hand, that the exercise of a constitutional privilege should under no circumstances subject a person to harsh consequences. Neither is helpful. The real issue under due process is whether or not it is reasonable for a state to adopt a measure which will reach the desired end of ridding government of some people who are incompetent to perform the duties of their offices, when such a measure is contradictory to some desirable, perhaps fundamental, procedural safeguards and may result in the dismissal of competent personnel.

\section{The Alternatives}

Advocates of the instant statutes argue that it is incongruous to allow employees to refuse to answer questions concerning the government which employs them. But this argument is a criticism of the privilege against self-incrimination which in itself involves an incongruity, since it is a method by which people may be permitted to conceal guilt. As Dean Wigmore points out, however, the privilege exists for the benefit of the innocent, not the guilty. ${ }^{85}$ In answer to this argument it may be contended that whereas there is no necessity to be "solicitous" towards the guilty, there is also no need to protect the innocent since the open courts of today provide sufficient safeguards. ${ }^{86}$ The difficulty, of course, is that such safeguards as do exist in the courts do not exist before legislative investigating committees. ${ }^{87}$ The fact is that the instant statutes are designed to apply to government personnel called to testify before such committees. The entire controversy revolves around the weighing of the public interest in complete disclosure of the facts against dangers to the individual inherent in the abolition or qualification of the self-incrimination privilege. At least in the area of government personnel, however, the conflict is not irreconcilable. There are alternatives to the instant type of statute which will at the same

85. 8 WIGMORE, EVIDENCE, §2250.

86. See Rapacz, Limiting The Plea of Self-Incrimination and Recent Enlargement of The New York Immminity Statutes, 20 GEO. L.J. 329 (1932).

87. See Coudert, Congressional Inquisition v. Individual Liberty, 15 VA. L. Rev. 537 (1929). 